\section{Who Wants to be a Scientist?}

Sir,- - I was shocked to read (Nature, 220, 424; 1968) that "Girls feel that science and mathematics are boys' subjects ... it is more important to girls to be considered attractive than brilliant ... Girls are also detorred because they feel that science and marriage do not mix; once they have spent a fow years producing a family their knowledge is out of date".

These statements are, of course, true--ihe shock came from the complacent acceptance of the inevitability of this odd point of view. That attitude is a major cause for shortages of scientists, physicians, surgeons and engineors in the western world. We are disqualifying 50 por cent of the population.

So far as I am aware, there is no evidence that the possession of ovaries qualifies or disqualifies a person for any particular mental activity--it merely reduces capacity for hard physical labour. The necessity for the latter qualification is rapidly decreasing in almost all fields of endeavour covered by higher forms of education.

One of the main reasons for the attitude of girls towards science is that they are trained from an early age by their mothers to regard sex-directed activities as a number one priority. Mothers display acute anxiety if their daughters are not interested in boy-friends and this pressure is developing at earlier and earlier ages. Few girls resist the drive to make them believe that their prime object in life is to get a man and produce a family. Men, too, want to have a wife and family, but they are not driven by society to regard this as their fundamental aim.

\section{Yours faithfully,}

C. A. Mawson

Box 15,

Deep River,

Ontario.

\section{Risk of an Astrodemic}

SIR,- The risk that astronauts returning from other celestial bodies might contaminate Earth with alien micro-organisms producing an astrodemic has not been adequately explored. Since the search for cxtraterrestrial life is given as a major purpose of space exploration, the chances that such life exists cannot be dismissed as negligible.

The announced prceautions designed to prevent terrestrial contamination are inadequate in two respects. First, a crash on return, such as the one that killed the Russian astronaut Komarov, could negate all isolation and quarantine plans and liberate alien micro-organisms or spores on Earth. Second, even if there were no crash, the planncd isolation and quarantine period of 3 weeks is quite insufficient. We know that several serious infectinus diseases on Farth may have incubation periods well over 3 weeks. Examples are tuberculosis, syphilis, rabies, leprosy, lymphogranuloma venereum, kala-azar, sporotrichosis and kuru. In most cases, the agents of these diseases cannot be reliably cultured in three weeks: some cannot be cultured at all. Surely a quarantine insufficient for so many scrious terrestrial diseases could hardly be considered adequate protection against unknown alien life forms.

Some scientists associated with space programmes play down risks from alien micro-organisms by referring to specificity of host requirements on the part of pathogens, but such specificity is not universal. Diseases like typhus fever and bubonic plague kill hosts of different phylla. There are even micro-organisms pathogenie for man and plants, including Sporotrichia, Cryptostroma corticale and Selerotinia selerotiorum. Also there are diseases referred to as "biological accidents" in which a product of a saprophyte or pathogen living on one form of life injures or kills a different life form ingesting it. Examples are botulism, ergotism and alimentary toxic aleukia. Host specificity based on long periods of evolution is not essential to disease production. Finally, there are the indirect hazards of ccntaminating Earth, those to domestic animals and plants.

Because all people will suffer if an astrodemic occurs, elementary fairness requires a broadening of the debate over Earth safety. The decision about the risk to Earth of any round trip ought not to be left to a space agency, to committees appointed by it, or to related government agencies. A judgment upon which the future of all life on Earth may depend should be made openly, after careful debate and consideration, by representatives of all peoples.

\section{Yours faithfully,}

\section{SOLOMON GaRB}

University of Missouri Medical School,

Columbia,

Missouri 65201.

\section{University News}

Dr G. R. Kelman has been appointed to the newly created chair of human physiology in the University of Aberdeen.

Dr G. A. Gilbert has been appointed to the newly designated chair of biochemistry in the Department of Chemistry, and Dr D. G. Harnden, MRC Clinical and Population Cytogenetics Research Unit, Edinburgh, has been appointed to the newly established chair of eancer studies in the Department of Pathology, in the University of Birmingham.

Dr H. Fernandez-Moran has been appointed A. N. Pritzker professor of biophysies in the Division of the Biological Sciences and the Pritzker School of Medicine of the University of Chicago.

Dr R. Gordon Hemingway has been appointed to the chair of animal husbandry in the University of Glasgow.

Professor J. R. Pappenheimer has been appointed George Higginson professor of physiology and Professor Todd Frazier has been appointed associate professor of biostatistics in the Faculty of Public Health and assistant director of the Center for Community Health and Medical Care at Harvard University.

The following appointments have been made in the University of London: Dr M. R. C. McDowell, Durham, to the chair of applied mathematies tenable at Royal Holloway College; Dr R. F. Streater, Imperial College, to the chair of applied mathematics at Bedford College ; Professor J. H. Wilkinson, Pennsylvania, to the chair of chemical pathology at Charing Cross Hospital School of Medicine.

\section{Appointments}

Mr M. W. Hill has been appointed keeper of the National Reference Library of Science and Invention, a part of the British Museum.

Dr A. Rowzee, Polymer Corporation, Sarnia, Canada, has been appointed president of the Society of Chemical Industry in succession to $\mathrm{Mr} \mathrm{N}$. Iliff.

Erratum. In the eommunication "Cardiovascular Changes during Proparation for Fighting Behaviour in the Cat" by David B. Adams et al. (Nature, 220, 1339; 1968), the fourth sentence of the second paragraph on page 1240 should read "If sympathetic dilatation of muscle vessels ever occurs during preparation for fighting, it must be completely concealed by an overwhelming vasoconstrictive influence". 


\section{International Meetings}

April 7-11, 6th Meeting of the Federation of European Biochemical Societies, Madrid (6th FEBS Meeting, Centro de Investigaciones Biologicas, Velazquez 144, Madrid 6, Spain).

April 15-16, Biophysical Studies of Cell Membranes, Birmingham (British Biophysical Society, c/o Institute of Biology, 41 Queens Gate, London SW7).

May 4-9, Electrochemical Society Meeting, New York (The Electrochemical Society, Inc., 30 East 42nd Street, New York, NY 10017, USA).

May 27-30, 3rd Congress of the European Thyroid Association, Athens (Dr C. Beckers, Cliniques Universitaires St Pierre, 69, Brusselsestraat, Louvain, Belgium).

June 1-14, Growth and Gharacterization of Electronic Materials, Chania, Crete (E. D. Haidemenakis, 2 rue de Furstenberg, Paris 6 e, France).

June 2-3, Polypeptides, their Chemical and Enzymatic Synthesis, their Role in Immunological Processes, New York City (Dr Edward G. Bassett, Symposium Coordinator, Research Products Division, Miles Laboratories, Inc., Elkhart, Indiana 46514, USA).

June 4-6, Automated Analysis, Chicago (Jerome E. Golin, Technicon Corporation, Ardsley, New York 10502, USA).

June 5-11, Forensic Sciences, Toronto (Mr D. M. Lucas, Fifth International Meeting of Forensic Sciences, 8 Jarvis Street, Toronto 2, Ontario, Canada).

June 15-28, Magnetism, Chania, Crete (E. D. Haidemenakis, 2 rue de Furstenberg, Paris 6 e, France).

June 16-20, Fuel Cells, Brussels (Troisiemes Journees Internationales d'Etude des Piles a Combustible, SERAI, 1091 Chaussee d'Alsemberg, Bruxelles 18, Belgium).

June 16-27, Physics of Quantum Electronics, Flagstaff, Arizona (S. F. Jacobs, Optical Sciences Center, University of Arizona, Tucson, Arizona 85721, USA).

June 30-July 1, Fibres for Composites : Strength, Structure and Stability, University of Sussex (Meetings Officer, Institute of Physics and the Physical Society, 47 Belgrave Square, London SW1).

June 30-July 3, Computer Science and Technology, Manchester (Institution of Electrical Engineers, Savoy Place, London WC2).

June 30-July 4, Operational Research-Reliability, Turin (Scientific Affairs Division, NATO, Brussels 39, Belgium).

July 7-11, Operational Research-Cost Benefit Analysis, The Hague (Scientific Affairs Division, NATO, Brussels 39, Belgium).

July 7-11, Applications of Mass Spectrometry in Chemical Research, Michigan (Engineering Summer Conferences, The University of Michigan, Chrysler Center, Department 265, Ann Arbor, Michigan 48105, USA).

July $8-10$, Three Body Problem in Nuclear and Particle Physics, Birmingham (Institute of Physies and the Physical Society, 47 Belgrave Square, London SW1). July 14-19, Optical Instruments and Techniques, Reading (Dr A. Thetford, New Applied Physical Science Building, The University, Whiteknights, Reading, England).

July 15-16, Enamine Chemistry, Salford (Dr P. W. Hickmott, Department of Chemistry, University of Salford, Salford M5 4WT, England).

July 15-19, Nuclear Magnetic Resonance Spectroscopy, Birmingham (Dr John F. Gibson, Scientific Affairs Officer, The Chemical Society, Burlington House, London WIV OBN).

\section{BRITISH DIARY}

\section{Monday, January 6}

Institution of Electrical Engineers (at Savoy Place, London, WC2), at $5.30 \mathrm{p} . \mathrm{m}$-Dr K. W. Plessner: "Dielectries for Energy Storage".

Institution of Electrical Fingineers (at Savoy Place, London, WC2), at 5.30 p.m.-Mr L. L. Freris and Mr A. M. Sasson: "An Investigation of the Load-Flow Problem",

Institution of Mechanical Engineers, Ntclear Energy Group (at 1 Birdcage Walk, Westminster, London, SW1), at 6 p.m.-Discussion meeting on "Numerical Estimation of Reliability of Engineering Equipment".

SOCIETY OF ChEMICAL INDUSTRY, LONDON SECTION; and the HEAVY ORGANIC CHEMICALS GROUP (at 14 Belgrave Square, London, sW1), a Present and Future".

\section{Tuesday, January 7}

INSTITUTION OF ElECTRICAL ENgINEERs (at Savoy Place, London, WC2)Colloquium on "Engineering Applications of Spectral Analysis".

Phytochemical SocIETy (at the School of Pharmacy, University of London)-Symposium on "Recent Work on Plant Products of Therapeutic London)",

Institution of Eleotrical Engineers (joint meeting with the Institute of Measurement and Control, and the Automatic Control Group of th Institution of Mechanical Engineers, at Savoy Place, London, WC2), at 5.30 p.m.-Professor J. K. Royle: "Fluidics".

INSTITUTION OF MECHANICAL ENGINEERS, RAILWAY ENGINEERING GROUP mecting on "New Materials and Techniques and their Effect on Design".

Tuesday, January 7-Wednesday, January 8

UnIVERstry of MANChester Institute of Sciexce AND Technology (at the Institute)-Symposium on "Recent Advances in Inorganic Reaction Mechanisms",

\section{Tuesday, January 7-Thursday, January 9} CHEMICAL SocIETY (in the University Chemical Laboratory, Lensfield
Road, Cambridge)-Symposium on "Orbital Symmetry Correlations in Organic Reactions",

\section{Wednesday, January 8}

Soctery of Chemicat Industry, Food Group (joint meeting with the Microbiology Group, at the Borough Polytechnic, London, SE1), at 6.15 p.m. -Symposium on "Microbiological Standards for Foods".

Wednesday, January 8-Thursday, January 9

Uyiversity of Manchester Institute of Solence and Technology (at the Institute)-Symposium on "Adsorption from Solution".

\section{Thursday, January 9}

British Biophysical Society, Physical Biochemistry Grovp (at the Department of Biochemistry, University of Birmingham)-Meeting on "Structural Applications of Flnorescence Techniques".

Mineralogical Societx (at the Geological Soriety of London, Burlington House, Piccadilly, London, W1), at 5 p.m.-Anniversary Meeting. Professor G. M. Brown: "The Mineralogy of Layered Basic Intrusions".

Institurion of Eleotrical ENernems (at Savoy Place, London, WC2), at $5.30 \mathrm{pm}$ - Mr D. T. Hollingsworth: "Underground Power Cables-Past, Present and Future"; (Eleventh Hunter Memorial Lecture).

Institution of Mechanical EngineERs, Edtcation and Training Grovp (at 1 Birdcage Walk, Westminster, Iondon, SW1), at 6 p.m.-Discussion meeting on "Carcers Guidance".

\section{Thursday, January 9-Friday, January 10}

BIOCHEMICAL SOCIETY (at the University, Manchester)-490th Meeting. Colloquium on "Control of Carbohydrate Metabolism"; Discussion Forum on "Enzymic Processes Involved in Polynucleotide Biosynthesis"; Pharmacological Biochemistry Group Meeting on "Metabolic Fate of Compounds Bound to Plasma Proteins".

\section{Friday, January 10}

INSTITCTION OF ELECTRICAL ENGINEERS, JOINT IEE/IERE COMPUTER Grovp (at Savoy Place, London, WC2)-Colloquium on "New Peripherals".

MINERALOGICAL SOCIETY; and the ROYAL MICROSCOPICAL SOCIETY (at the Geological Society of London, Burlington House, Piccadilly, London, W1)Meeting on "Microscopic Techniques and their Application in Mineralogy and Ceramic Materials".

\section{Monday, January 13}

Institution of Mechanical Engineers, Manufactura and ManageMENT GROUP (at 1 Birdcage Walk, Westminster, London, SW 1 ), at 6 p.m. Discussion meeting on "Making the Most of the Industrial "Training Act".

\section{REPORTS and other PUBLICATIONS}

(not included in the monthly Books Supplement)

\section{Great Britain and Ireland}

Ministry of Health: Seottish Home and Health Department. Central Health Services Council: Scottish Health Services Council. Hospital Treatment of Acute Poisoning: Report of the Joint Sub-Committee of the Standing Medical Advisory Committecs. Pp. 34. (London: H.M. Stationery
Office, 1968.) $3 s, 6 d$. net. 